\title{
On- versus Off-Pump Coronary Artery Bypass Grafting: No Difference in Early Postoperative Kidney Function Based on TNF- $\alpha$ or C-Reactive Protein
}

\author{
Nariman Nezami ${ }^{a}$ Hassan Djavadzadegan ${ }^{b}$ Haleh Tabatabaie-Adl ${ }^{b}$ \\ Amir Hamdi $^{d}$ Kazem Ghobadi ${ }^{b}$ Sona Ghorashic Babak Hajhosseini ${ }^{\mathrm{e}}$ \\ ${ }^{a}$ Drug Applied Research Center and ${ }^{b}$ Department of Cardiology, Tabriz University of Medical Sciences, and

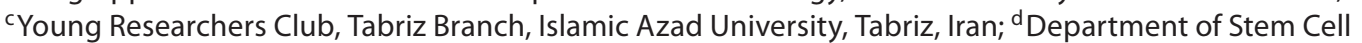 \\ Transplantation and Cellular Therapy, The University of Texas MD Anderson Cancer Center, Houston, Tex., \\ and ' Department of Surgery, Keck School of Medicine, University of Southern California, Los Angeles, Calif., USA
}

\author{
Key Words \\ Coronary artery bypass grafting $\cdot$ Renal function $\cdot C$-reactive protein $\cdot$ Tumor necrosis \\ factor- $\alpha \cdot$ On-pump $\cdot$ Off-pump $\cdot$ Cardiopulmonary bypass $\cdot$ Cardiac surgery
}

\begin{abstract}
Background/Aims: There are controversial data about renal function following off-pump coronary artery bypass grafting (CABG). The present study aimed to evaluate renal function changes $24 \mathrm{~h}$ after on- and off-pump CABG, as well as renal function correlated with high-sensitivity C-reactive protein (hs-CRP) and tumor necrosis factor- $\alpha$ (TNF- $\alpha$ ). Methods: Ninety patients with coronary artery disease referred to our center for CABG from July 2006 to November 2007 were enrolled in the study. Patients were equally and randomly divided in two groups, on- and offpump. Serum levels of creatinine $(\mathrm{Cr})$, blood urea nitrogen, creatinine clearance $(\mathrm{CrCl}), \mathrm{hs}-\mathrm{CRP}$, and TNF- $\alpha$ were determined immediately before and $24 \mathrm{~h}$ after surgery. Results: $\mathrm{Cr}$ and $\mathrm{CrCl}$ changes after surgery were not significantly different between the two groups; however, blood urea nitrogen levels after surgery were significantly higher in the on-pump group $(p=0.035)$. No statistically significant difference was noted between the two groups in terms of changes in levels of hs-CRP and TNF- $\alpha$ ( $p=0.350$ and 0.805 , respectively). The changes in $\mathrm{CrCl}$ levels had no significant correlation with hs-CRP and TNF- $\alpha$. Conclusions: The early $\mathrm{Cr}$ and $\mathrm{CrCl}$ levels after surgery are not significantly different in on- and off-pump groups. The early renal function after on- or off-pump CABG is not correlated with the levels of inflammatory markers including hsCRP and TNF- $\alpha$.




\section{CardioRenal Medicine}

\begin{tabular}{l|l}
\hline \multicolumn{2}{l}{ Cardiorenal Med 2012;2:190-199 } \\
\hline DOI: $10.1159 / 000339171$ \\
Published online: June 27, 2012 & $\begin{array}{l}\text { @ 2012 S. Karger AG, Basel } \\
\text { www.karger.com/crm }\end{array}$ \\
\hline
\end{tabular}

Nezami et al.: On- versus Off-Pump Coronary Artery Bypass Grafting: No Difference in

Early Postoperative Kidney Function Based on TNF- $\alpha$ or C-Reactive Protein

\section{Introduction}

Coronary artery bypass grafting (CABG) is one of the most frequently performed operations worldwide. Since the incidence of coronary artery disease and, subsequently, the number of CABGs performed continue to rise, any improvement in the safety and efficacy of the procedure would have a major impact on the outcomes [1,2].

Despite advances in methods and technologies, postoperative acute renal insufficiency continues to be a significant cause of morbidity and mortality after cardiac operations performed through the on-pump method using cardiopulmonary bypass (CPB). The etiology of this condition is multifactorial, including the factors related to conduct and management of CABG such as bypass time, use of vasopressors before CABG, systemic inflammatory response, hypoperfusion, and loss of pulsatile perfusion [3]. As CPB has pathophysiologic sequels, there has been a revival of interest in performing CABG on a beating heart (off-pump method) [4]. Proponents of off-pump CABG emphasize decreased incidences of postoperative neurological dysfunction, myocardial infarction, bleeding, renal failure, and respiratory failure [5]; however, controversies exist regarding the changes on renal function following off-pump CABG.

Furthermore, it is known that the $\mathrm{CPB}$ and pulmonary-myocardial reperfusion during on-pump CABG activate the innate and adaptive immune systems. The extent of this immune reaction has been linked to postoperative complications seen in this type of surgery [6]. Therefore, the avoidance of CPB and subsequent myocardial ischemia reperfusion has been proposed to significantly reduce postoperative complications, one of which is renal dysfunction [7]. It is known that systemic inflammatory response plays a major role in perioperative complications. Interleukin (IL)-1b, IL-6, IL-8, and tumor necrosis factor- $\alpha$ (TNF- $\alpha$ ) are produced in the acute phase of the inflammatory response, and high-sensitivity C-reactive protein (hs-CRP) has been shown to correlate with multi-organ failure [8-10]. We aimed to investigate the changes in renal function after on- and off-pump CABG and their association with hs-CRP and TNF- $\alpha$ for the first time.

\section{Materials and Methods}

\section{Patients and Study Design}

This is a prospective case-control study which was conducted in Shahid Madani Hospital of Tabriz University of Medical Sciences in Tabriz, Iran. Data were collected from July 2008 to July 2009.

Different blinded researchers conducted each part of the study including random assignment of the patients to each group (blocked randomization by varying the size of the blocks from 2 to 8), collecting samples, laboratory evaluations, and data analysis. Ninety patients with coronary artery disease referred to our center for CABG were enrolled in the study. All the patients met the criteria for CABG based on the American College of Cardiology/American Heart Association guideline [11]. Afterwards, patients were divided randomly into the on- and off-pump CABG groups, 45 cases in each group. All the surgeries were conducted by the same surgical team.

The study was approved by the Institutional Review Board of Tabriz University of Medical Sciences and was in compliance of the Helsinki Declaration. All patients gave informed consent for participation in the study.

Inclusion criteria included age between 45 and 65 years; no history of neoplastic diseases including benign and malignant tumors; no recent history of steroid or non-steroidal anti-inflammatory drug therapy in the last 2 weeks before surgery; no history of respiratory failure including asthma, adult respiratory distress syndrome, prolonged mechanical ventilation, and acute lung injury; no history of rheumatologic diseases including gout, lupus, dermatomyositis, polymyositis, sclerodermia, rheumatoid arthritis, and osteoarthritis; no history of autoimmune neurologic diseases including myasthenia gravis and multiple sclerosis; no history of chronic hematologic and oncologic disorders including hemolytic anemia and idiopathic and thrombotic thrombocytopenic purpura; no insulin-dependent diabetes; no 


\section{CardioRenal Medicine}

acute/chronic renal failure, determined by creatinine clearance $(\mathrm{CrCl})$ using Cockroft-Gault equation [12] $\leq 50 \mathrm{ml} / \mathrm{min}$, and no recent active infectious diseases. Presence of any major complications during $24 \mathrm{~h}$ after surgery including cardiac arrest and inability to obtain serum samples were considered as exclusion criteria.

\section{Surgical Management}

On-Pump CABG Method

Cefazoline (Kefzol; $1 \mathrm{~g}$ ) was given for preoperative antibiotic prophylaxis. Anesthesia was induced with etomidate (Amidate; $200-300 \mathrm{mg} / \mathrm{kg}$ ) and fentanyl (Sublimaze; $20-30 \mathrm{mg} / \mathrm{kg}$ ). After muscle relaxation with cisatrocurium (Nimbex; $0.15 \mathrm{mg} / \mathrm{kg}$ ) and endotracheal intubation, anesthesia was maintained using fentanyl (Sublimaze), midazolam (Versed; http://en.wikipedia.org/wiki/Midazolam) and isoflurane $(0.4-1.5 \%)$.

The CPB equipment included nonpulsatile roller pumps (Stoeckert, Munich, Germany) and membrane oxygenators (Affinity, Avecor Cardiovascular, Plymouth, Mass., USA). The pump was primed with

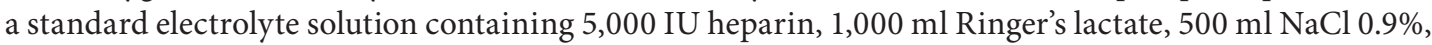
and $250 \mathrm{ml}$ of a 15\% mannitol solution (Osmofundin 15\% N; Braun Melsungen, Melsungen, Germany). Heparin $(300 \mathrm{IU} / \mathrm{kg}$ ) was administered immediately before vascular cannulation. After the institution of $\mathrm{CPB}$ at a flow rate of $2.4-3 \mathrm{l} / \mathrm{m}^{2} / \mathrm{min}$, the aorta was cross clamped and a bloody cardioplegic solution was injected. After CPB, protamine sulfate was infused.

\section{Off-Pump CABG Method}

The same perioperative management steps described for the on-pump CABG method were applied here; this includes induction of anesthesia, endotracheal intubation, and the maintenance of anesthesia.

Once the pericardium was opened, an initial heparin dose of $2 \mathrm{mg} / \mathrm{kg}$ was administered. Intravenous heparin was then used to maintain an activated clotting time of $>350$ s until the anastomoses were created. An Octopus stabilizer system (Medtronic Inc., Minneapolis, Minn., USA) was used during the operation. After incision of the coronary artery, an intracoronary shunt was inserted and an anastomosis was performed.

Following revascularization, the heparin effect was reversed with protamine sulfate (at a ratio of 1.5:1).

\section{Blood Sampling}

Venous blood samples were taken immediately before operation and $24 \mathrm{~h}$ after operation. Samples were collected in sterile tubes, centrifuged at 3,000 r.p.m. for $10 \mathrm{~min}$ at $4^{\circ} \mathrm{C}$, and then stored at $-79^{\circ} \mathrm{C}$ until assayed.

\section{General Parameters}

General parameters studied included age; sex; weight; history of disease including hypertension, diabetes, and hyperlipidemia; history of smoking and drug history; family history; the number of involved coronary arteries; graft type, and ejection fraction.

\section{Biochemical Parameters}

Serum levels of creatinine ( $\mathrm{Cr}$ ) and blood urea nitrogen (BUN) were measured using an automated chemical analyzer (Abbott analyzer, Abbott laboratories, Abbott Park, North Chicago, Ill., USA) with commercial reagents obtained from Pars Azmoon Laboratories Ltd. (Tehran, Iran). CrCl was determined by using the standard formula - Cockroft-Gault equation [12].

\section{Inflammatory Parameters}

Levels of hs-CRP and TNF- $\alpha$ were measured by the ELISA method using commercial kits (hs-CRP by Monobind Inc., Calif., USA, Lot No. EIA-1K2L7, and TNF- $\alpha$ by Human TNF- $\alpha$ ELISA, Bender MedSystems, Vienna, Austria, Lot No. 41881009).

\section{Statistical Analyses}

Statistical analyses were performed using the SPSS statistical package version 13.0 (SPSS Inc., Chicago, Ill., USA). The quantitative data are presented as means \pm SD, and the qualitative data are expressed as numbers and percentages. The Kolmogorov-Smirnov test was used to assess the normality. Indepen- 


\section{CardioRenal Medicine}

\begin{tabular}{|c|c|}
\hline \multicolumn{2}{|l|}{ Cardiorenal Med 2012;2:190-199 } \\
\hline $\begin{array}{l}\text { DOI: } 10.1159 / 000339171 \\
\text { Published online: June 27, } 2012\end{array}$ & $\begin{array}{l}\text { (c) } 2012 \text { S. Karger AG, Basel } \\
\text { www.karger.com/crm }\end{array}$ \\
\hline
\end{tabular}

Table 1. Demographic characteristics of studied population and comparison between the groups

\begin{tabular}{llll}
\hline & \multicolumn{2}{l}{ Type of CABG surgery } & \multirow{2}{*}{$\mathrm{p}$} \\
\cline { 2 - 3 } & off-pump $(\mathrm{n}=45)$ & on-pump $(\mathrm{n}=45)$ & \\
\hline Age, years & $58.08 \pm 5.10$ & $59.24 \pm 4.24$ & 0.267 \\
Weight, kg & $77.54 \pm 8.74$ & $73.17 \pm 8.98$ & 0.087 \\
Ejection fraction, \% & $43.85 \pm 9.32$ & $45.45 \pm 8.27$ & 0.423 \\
Smoking & $28(62.22)$ & $27(60)$ & 0.470 \\
Uncontrolled hypertension & $11(24.44)$ & $15(33.34)$ & 0.144 \\
Diabetes mellitus & $9(20)$ & $9(20)$ & 1 \\
Hyperlipidemia & $10(22.22)$ & $15(33.34)$ & 0.391 \\
Number of grafts one/two/three vessels & $2 / 15 / 28$ & $0 / 14 / 31$ & 0.201 \\
Type of graft LIMA/SVG/both & $10 / 3 / 32$ & $6 / 0 / 39$ & 0.125 \\
Surgery duration, min & $352.66 \pm 37.94$ & $331.85 \pm 20.11$ & 0.176 \\
\hline
\end{tabular}

Values are means \pm SD or numbers with percentages in parentheses unless otherwise indicated.

LIMA = Left internal mammary artery; SVG = saphenous vein graft.

dent sample/paired t tests, and Mann-Whitney $\mathrm{U}$ and Wilcoxon signed rank tests were used to assess the differences between stages when applied. Comparison of qualitative data was also performed by $\chi^{2}$ test and correlation assessed using Pearson's correlation test. Also, multivariable analysis using a multiple regression test was carried out to assess effects of the type of surgery and of the changes in levels of hs-CRP and TNF- $\alpha$ on the $\mathrm{CrCl}$ changes. A p value $<0.05$ was considered significant.

\section{Results}

The demographic characteristics of patients are shown in table 1. There was no significant difference between the two groups in terms of age, weight, history of smoking, uncontrolled hypertension, diabetes mellitus, hyperlipidemia, left ventricular ejection fraction, number of bypassed arteries, type of graft, and blood/Rho groups. Also, as shown in table 2, there were no significant differences between the two groups in terms of the medications they were on before surgery.

As demonstrated in table 3 and figures 1, 2, and 3, preoperative levels of serum Cr, BUN, and $\mathrm{CrCl}$ were not significantly different between off- and on-pump groups. Postoperative levels of $\mathrm{Cr}$ and $\mathrm{CrCl}$ between the two groups were not significantly different either; however, postoperative BUN levels were significantly higher in the on-pump group compared to the off-pump group $(\mathrm{p}=0.035)$. Intragroup comparison of the off-pump group showed no significant changes in levels of $\mathrm{Cr}, \mathrm{BUN}$, and $\mathrm{CrCl}$ before and after surgery ( $\mathrm{p}=0.537,0.497$, and 0.932 , respectively). In the on-pump group, although $\mathrm{Cr}$ and $\mathrm{CrCl}$ levels were not significantly changed ( $\mathrm{p}=0.934$ and 0.480 , respectively), BUN levels were significantly increased after surgery compared to before surgery $(\mathrm{p}=0.020)$.

In both off- and on-pump groups, hs-CRP levels after CABG surgery were significantly increased ( $p<0.001$ for both); however, the amount of increase $(\Delta$ hs-CRP $=$ postsurgical hs$\mathrm{CRP}$ - presurgical hs-CRP) was not significantly different in the off-pump group compared to the on-pump group (table 4). Postsurgical levels of TNF- $\alpha$ did not differ significantly in either group compared to the presurgical levels $(\mathrm{p}=0.171$ and 0.710 , respectively); the amount of change in TNF- $\alpha$ level $(\Delta$ TNF- $\alpha=$ postsurgical TNF- $\alpha-$ presurgical TNF- $\alpha$ ) was not significantly different comparing the two groups either (table 4). 


\section{CardioRenal Medicine}

\begin{tabular}{|c|c|}
\hline \multicolumn{2}{|l|}{ Cardiorenal Med 2012;2:190-199 } \\
\hline $\begin{array}{l}\text { DOI: } 10.1159 / 000339171 \\
\text { Published online: June } 27,2012\end{array}$ & $\begin{array}{l}\text { (c) } 2012 \text { S. Karger AG, Basel } \\
\text { www.karger.com/crm }\end{array}$ \\
\hline
\end{tabular}

Table 2. Medication history of participants

\begin{tabular}{|c|c|c|c|c|}
\hline \multirow[t]{2}{*}{ Drug type } & \multirow[t]{2}{*}{ Drug subgroup } & \multicolumn{2}{|c|}{ Type of CABG surgery } & \multirow[t]{2}{*}{$\mathrm{p}$} \\
\hline & & $\begin{array}{l}\text { off-pump } \\
(\mathrm{n}=45)\end{array}$ & $\begin{array}{l}\text { on-pump } \\
(\mathrm{n}=45)\end{array}$ & \\
\hline ACE-I/ARBs & $\begin{array}{l}\text { Captopril (Capoten)/enalapril (Vasotec) } \\
\text { Losartan (Cozaar) }\end{array}$ & $\begin{aligned} 15 & (33.34) \\
3 & (6.66)\end{aligned}$ & $\begin{array}{l}18(40) \\
5(11.11)\end{array}$ & 0.207 \\
\hline$\beta$-Blocker & & $36(80)$ & $39(86.66)$ & 0.248 \\
\hline Ca channel blocker & $\begin{array}{l}\text { Dihydropyridin } \\
\text { Non-dihydropyridin }\end{array}$ & $\begin{array}{l}6(13.33) \\
2(4.44)\end{array}$ & $\begin{array}{l}9(20) \\
2(4.44)\end{array}$ & 0.729 \\
\hline Digoxin (Lanoxin) & & $2(4.44)$ & $4(8.88)$ & 0.691 \\
\hline Anticoagulant & $\begin{array}{l}\text { Aspirin (USAN) } \\
\text { Enoxaparin (Xaparin) }\end{array}$ & $\begin{array}{c}30(66.66) \\
1(2.22)\end{array}$ & $\begin{array}{l}32(71.11) \\
1(2.22)\end{array}$ & 0.874 \\
\hline Diuretic & $\begin{array}{l}\text { Thyazids } \\
\text { Furosemide (Lasix) } \\
\text { Spironolactone (Aldactone) }\end{array}$ & $\begin{array}{l}0 \\
0 \\
1(2.22)\end{array}$ & $\begin{array}{l}1(2.22) \\
2(4.44) \\
1(2.22)\end{array}$ & 0.486 \\
\hline Statins & & $38(84.44)$ & $30(66.66)$ & 0.099 \\
\hline Nitrates & $\begin{array}{l}\text { Nitrocontin } \\
\text { Nitroglycerin }\end{array}$ & $\begin{array}{l}25(55.55) \\
26(57.77)\end{array}$ & $\begin{array}{l}2(4.44) \\
3(6.66)\end{array}$ & 0.798 \\
\hline
\end{tabular}

Values are numbers with percentages in parentheses.

ACE-I = Angiotensin-converting enzyme inhibitor; $\mathrm{Ca}=$ calcium .

Table 3. Compression of renal function parameters between on-pump and off-pump methods, and before and after operation

\begin{tabular}{|c|c|c|c|c|}
\hline & & \multicolumn{2}{|c|}{ Type of CABG surgery } & \multirow[t]{2}{*}{$\mathrm{p}$} \\
\hline & & $\begin{array}{l}\text { off-pump } \\
(\mathrm{n}=45)\end{array}$ & $\begin{array}{l}\text { on-pump } \\
(\mathrm{n}=45)\end{array}$ & \\
\hline $\mathrm{Cr}, \mathrm{mg} / \mathrm{dl}$ & $\begin{array}{l}\text { Before } \\
\text { After }\end{array}$ & $\begin{array}{l}1.03 \pm 0.28 \\
1.01 \pm 0.19\end{array}$ & $\begin{array}{l}1.03 \pm 0.17 \\
1.04 \pm 0.18\end{array}$ & $\begin{array}{l}0.918 \\
0.772\end{array}$ \\
\hline$\Delta \mathrm{Cr}, \mathrm{mg} / \mathrm{dl}$ & & $-0.02 \pm 0.18$ & $0.00 \pm 0.19$ & 0.631 \\
\hline $\mathrm{CrCl}, \mathrm{ml} / \mathrm{min}$ & $\begin{array}{l}\text { Before } \\
\text { After }\end{array}$ & $\begin{array}{l}103.98 \pm 28.80 \\
103.15 \pm 21.12\end{array}$ & $\begin{array}{r}102.13 \pm 16.37 \\
99.49 \pm 12.80\end{array}$ & $\begin{array}{l}0.536 \\
0.351\end{array}$ \\
\hline$\Delta \mathrm{CrCl}, \mathrm{ml} / \mathrm{min}$ & & $-0.35 \pm 18.66$ & $-3.69 \pm 19.74$ & 0.608 \\
\hline BUN, mg/dl & $\begin{array}{l}\text { Before } \\
\text { After }\end{array}$ & $\begin{array}{l}16.08 \pm 6.69 \\
16.86 \pm 5.74\end{array}$ & $\begin{array}{l}16.28 \pm 4.41 \\
20.31 \pm 6.45\end{array}$ & $\begin{array}{l}0.609 \\
0.035\end{array}$ \\
\hline$\Delta \mathrm{BUN}, \mathrm{mg} / \mathrm{dl}$ & & $1.00 \pm 0.15$ & $3.45 \pm 8.33$ & 0.136 \\
\hline
\end{tabular}

Values are means $\pm \mathrm{SD}$.

$\Delta \mathrm{Cr}=\mathrm{Cr}$ level after surgery $-\mathrm{Cr}$ level before surgery; $\Delta \mathrm{CrCl}=\mathrm{CrCl}$ level after surgery $-\mathrm{CrCl}$ level before surgery; $\triangle \mathrm{BUN}=\mathrm{BUN}$ level after surgery $-\mathrm{BUN}$ level before surgery. 


\section{CardioRenal \\ Medicine}

Fig. 1. Cr levels following CABG.

Fig. 2. $\mathrm{CrCl}$ levels following CABG.

Fig. 3. BUN levels following CABG.
Cardiorenal Med 2012;2:190-199

DOI: 10.1159/000339171

(c) 2012 S. Karger AG, Basel

www.karger.com/crm

195

Nezami et al.: On- versus Off-Pump Coronary Artery Bypass Grafting: No Difference in Early Postoperative Kidney Function Based on TNF- $\alpha$ or C-Reactive Protein

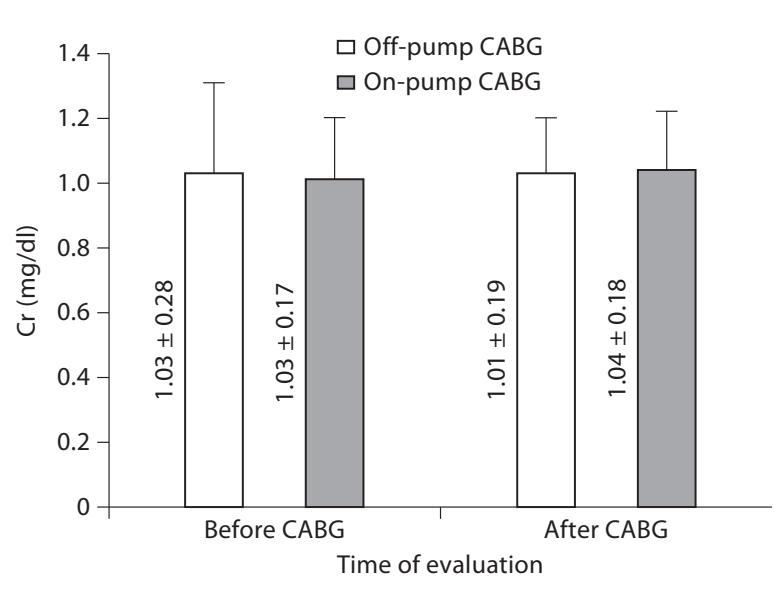

Time of evaluation
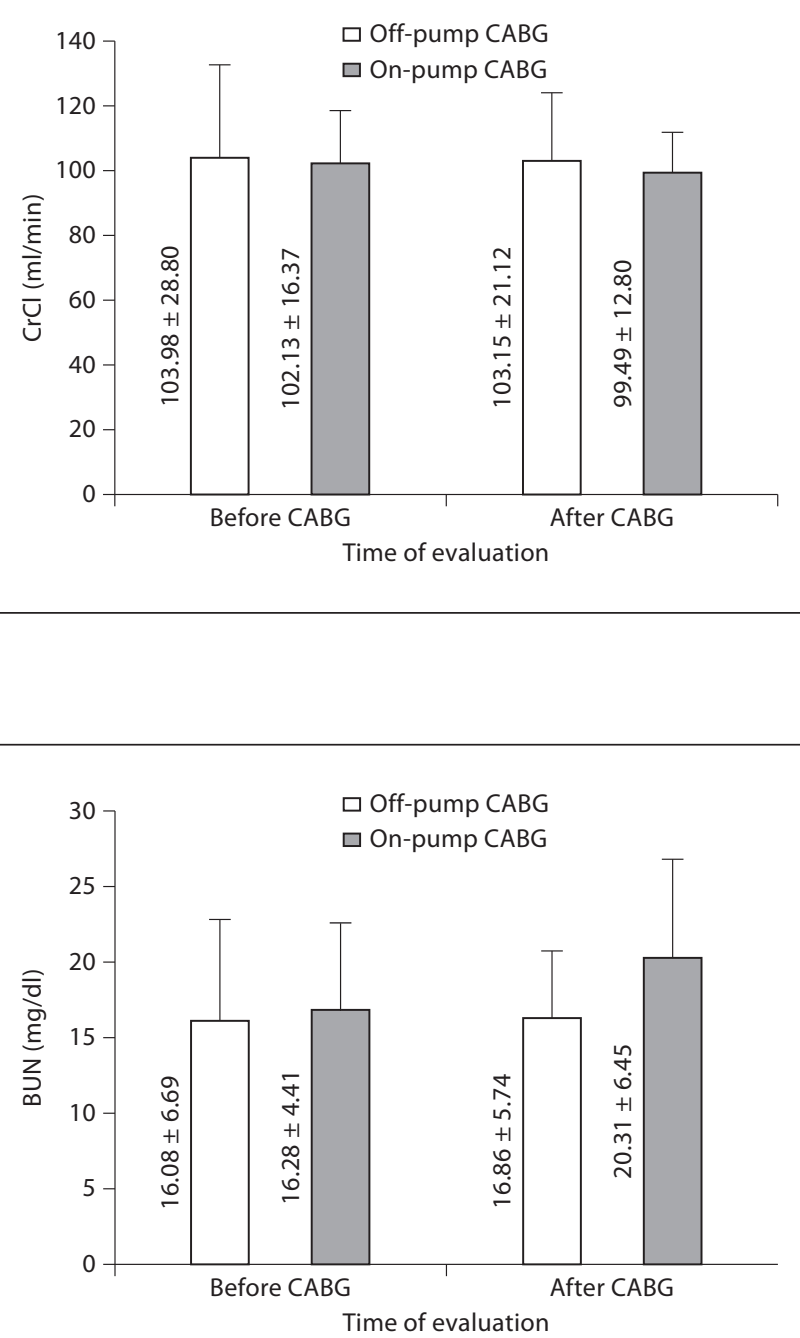
Table 4. Comparison of hs-CRP and TNF- $\alpha$ levels between on-pump and off-pump groups

\begin{tabular}{lccc}
\hline & \multicolumn{2}{l}{ Type of CABG surgery } & $\mathrm{p}$ \\
\cline { 2 - 3 } & $\begin{array}{l}\text { off-pump } \\
\text { (n=45) }\end{array}$ & $\begin{array}{l}\text { on-pump } \\
(\mathrm{n}=45)\end{array}$ & \\
\hline hs-CRP before surgery, $\mathrm{mg} / \mathrm{dl}$ & $10.91 \pm 14.92$ & $10.77 \pm 14.77$ & 0.967 \\
hs-CRP after surgery, $\mathrm{mg} / \mathrm{dl}$ & $136.06 \pm 88.76$ & $116.07 \pm 92.97$ & 0.338 \\
TNF- $\alpha$ before surgery, pg/ml & $12.63 \pm 12.11$ & $12.69 \pm 11.77$ & 0.790 \\
TNF- $\alpha$ after surgery, pg/ml & $14.50 \pm 12.50$ & $14.25 \pm 11.33$ & 0.953 \\
$\Delta$ hs-CRP, mg/dl & $105.15 \pm 95.58$ & $125.28 \pm 91.92$ & 0.350 \\
$\Delta$ TNF- $\alpha, \mathrm{pg} / \mathrm{ml}$ & $0.86 \pm 5.24$ & $1.55 \pm 6.58$ & 0.805 \\
\hline
\end{tabular}

Values are means \pm SD.

Also, there was no significant correlation between the level of $\mathrm{Cr}, \mathrm{BUN}$, and $\mathrm{CrCl}$ changes and $\Delta$ hs-CRP ( $\mathrm{p}=0.910,0.335$, and 0.947 , respectively) or $\Delta$ TNF- $\alpha(\mathrm{p}=0.193,0.450$, and 0.081 , respectively) in either group.

Hierarchical multiple regression was used to assess the effect of the type of surgery and the amount of change in hs-CRP and TNF- $\alpha$ levels on $\mathrm{CrCl}$ after controlling for the influence of demographic characters and lipid profiles. After entry of the type of surgery and changes of hs-CRP and TNF- $\alpha$ levels, the total variance explained by the model as a whole was $51.5 \%[\mathrm{~F}(10,25)=2.653, \mathrm{p}=0.023]$. These factors explained an additional 10.45 of the variance in $\mathrm{CrCl}$ changes after controlling for demographic characters and lipid profiles $\left[\mathrm{R}^{2}\right.$ change $=0.104, \mathrm{~F}$ change $(3,25)=1.789, \mathrm{p}=0.175]$. In the final model, only the two control variables significantly affected $\mathrm{CrCl}$ changes, with the hypertension history recoding a higher $\beta$ value $(\beta=-0.545, p=0.001)$ than the weight of patients $(\beta=-0.383, p=0.017)$.

\section{Discussion}

Results of the present study demonstrated that renal function - measured by Cr and $\mathrm{CrCl}$ - following $\mathrm{CABG}$ was not significantly different in patients undergoing on-pump or off-pump methods. The changes in renal function following both methods were related neither to the levels of hs-CRP nor TNF- $\alpha$. We were able to successfully control for major confounding factors which could potentially affect the postsurgical renal function including demographic characteristics, concomitant diseases, number of bypassed arteries, duration of surgery, medication history, and preoperative renal function. Furthermore, none of the patients had $\mathrm{CrCl}<50 \mathrm{ml} / \mathrm{min}$ before or after surgery.

Previous studies have compared the degree of renal injury after on- and off-pump procedures. Some of these studies have emphasized biochemical markers of renal injury while others have primarily focused on clinical parameters. In one randomized trial, it was shown that $\mathrm{CrCl}$ was significantly higher in the on-pump group intraoperatively, but it deteriorated during the first $48 \mathrm{~h}$ postoperatively compared to off-pump patients. In the same study, urinary $\mathrm{N}$-acetyl-b-glucosaminidase (NAG), a marker for renal tubular damage, remained significantly lower in the off-pump group, both during and after surgery [13]. Another study reported increased signs of oxidative stress - as measured by urinary concentrations of hypoxanthine, xanthine, and malondialdehyde - in the on-pump group, while only minimal changes were reported in the off-pump group [4]. A randomized study found that off-pump 


\section{CardioRenal Medicine}

\begin{tabular}{l|l}
\hline \multicolumn{2}{l}{ Cardiorenal Med 2012;2:190-199 } \\
\hline $\begin{array}{l}\text { DOI: 10.1159/000339171 } \\
\text { Published online: June 27, 2012 }\end{array}$ & $\begin{array}{l}\text { ○ } 2012 \text { S. Karger AG, Basel } \\
\text { www.karger.com/crm }\end{array}$ \\
\hline $\begin{array}{l}\text { Nezami et al.: On- versus Off-Pump Coronary Artery Bypass Grafting: No Difference in } \\
\text { Early Postoperative Kidney Function Based on TNF- } \alpha \text { or C-Reactive Protein }\end{array}$
\end{tabular}

CABG induced fewer biochemical markers of renal injury including microalbuminuria, free water clearance, NAG levels, and free hemoglobin [14]; however, these parameters were not found to be different between on- and off-pump groups in a different randomized study [15]. Another case-controlled trial found that serum Cr levels were significantly lower and $\mathrm{CrCl}$ was significantly higher in the off-pump group compared to the on-pump group [16]. Karthik et al. [17] constructed a propensity score for risk-adjusted comparison of patients undergoing nonelective on- and off-pump CABG. The incidence of renal impairment, as assessed by an increase in Cr level $>1.5 \mathrm{mg} / \mathrm{ml}$, was significantly higher in the on-pump group. In a similar analysis of propensity-matched pairs of patients, the rate of renal failure requiring dialysis was $1.5 \%$ in the on-pump group versus none in the off-pump group [7]. The incidence of postoperative dialysis in a large cohort of diabetic patients undergoing off-pump CABG was 0.87 versus $2.75 \%$ in the on-pump group, while the rate of renal failure not requiring dialysis was similar between the two groups [18]. In a recent meta-analysis, the rate of renal failure was lower in off-pump patients [19]. A recent meta-analysis of randomized and observational studies carried out by Nigwekar et al. [1] showed that patients undergoing off-pump CABG surgery were prone to renal injury and failure despite the different acute kidney injury definitions used in the enrolled studies. As it is evident, the literature reflects controversial evidence regarding renal impairment following on-pump and off-pump surgeries. The results of our study showed no difference in $\mathrm{Cr}$ and $\mathrm{CrCl}$ levels following on-pump and off-pump techniques; however, BUN levels were higher in the on-pump group, which was associated with using CPB.

It is well recognized that CABG may lead to major organ dysfunction including, but not limited to, renal injury. However, the role of an extracorporeal circulation device in the development of renal injury is not entirely clear. CPB is associated with the development of systemic inflammatory response, endothelial damage, and subsequent tissue edema and organ dysfunction. Interestingly, systemic inflammation is also observed in patients undergoing off-CPB cardiac surgery, albeit on a smaller scale [20]. Although hs-CRP and TNF- $\alpha$ levels were increased after both on- and off-pump surgery in our study, it was statistically significant only in terms of hs-CRP level. More importantly, we found that renal function was related neither to hs-CRP nor TNF- $\alpha$.

The results of the present study did not show a consistent association between the inflammatory biomarkers and renal function, while prior cross-sectional studies have shown such association. Some studies found associations between renal function and CRP [21], while others revealed a direct relationship between cystatin C and CRP, IL- 6 , and TNF- $\alpha$ and its two soluble receptors [22]. Considering a significant increase in CRP levels following on-pump CABG, some consequences could be expected including activation of coagulation, down-regulation of physiological anticoagulant mechanisms, and inhibition of fibrinolysis $[23,24]$, all of which predispose CABG patients to major organ dysfunction such as renal injury. However, during the last decade, the practice of the CPB has benefited from major refinements and improvements in the field of biocompatibility, such as the introduction of warm heart surgery, coated circuits, anti-fibrinolytic drugs, and the elimination of cardiotomy suckers. Warm cardioplegia seems to reduce the oxidative stress [25-27] and inflammatory response $[28,29]$.

We acknowledge the limitations inherent in our study including single-sex patient population, small sample size, and short duration of follow-up. We continue to gather data from a larger group of patients for our future studies. Additionally, better renal function biomarkers (e.g. cystatin C) have since been introduced which were not available at the time we conducted our study.

In conclusion, none of our patients in either group developed renal failure, and renal function, determined by early postoperative $\mathrm{Cr}$ and $\mathrm{CrCl}$ levels, was not different between 


\section{CardioRenal Medicine}

\begin{tabular}{l|l}
\hline Cardiorenal Med 2012;2:190-199 \\
\hline DOI: 10.1159/000339171 & $\begin{array}{l}\text { @ 2012 S. Karger AG, Basel } \\
\text { www.karger.com/crm }\end{array}$ \\
\hline Published online: June 27, 2012
\end{tabular}

Nezami et al.: On- versus Off-Pump Coronary Artery Bypass Grafting: No Difference in

Early Postoperative Kidney Function Based on TNF- $\alpha$ or C-Reactive Protein

the on- and off-pump groups. Also, on-pump CABG patients developed mild decrease in renal dysfunction, although within a normal range, and the use of CPB did not result in postoperative $\mathrm{CrCl}$ of $<50 \mathrm{ml} / \mathrm{min}$ after on-pump CABG. These insignificant changes in renal function were independent of inflammatory markers.

\section{Acknowledgements}

The present study was supported by the Drug Applied Research Center of Tabriz University of Medical Sciences. The authors thank Ms. Roghaye Rastghoo, Dr. Ali Akbar Abolfathi, Dr. Hassan Argani, Dr. Hossein Babaie, Dr. Behzad Salari, Dr. Alireza Sadighi, Dr. Aimaz Afrough, Dr. Arash Tafrishinejad, Ms. Azra Nezamizadeh, and Ms. Nastaran Ghodratnejad.

\section{Disclosure Statement}

The authors have no proprietary interest in any aspect of this study.

\section{References}

1 Nigwekar SU, Kandula P, Hix JK, Thakar CV: Off-pump coronary artery bypass surgery and acute kidney injury: a meta-analysis of randomized and observational studies. Am J Kidney Dis 2009;54:413-423.

-2 Yacoub M: Off-pump coronary bypass surgery: in search of an identity. Circulation 2001;104:1743-1745.

-3 Regragui IA, Izzat MB, Birdi I, Lapsley M, Bryan AJ, Angelini GD: Cardiopulmonary bypass perfusion temperature does not influence perioperative renal function. Ann Thorac Surg 1995;60:160-164.

4 Ascione R, Lloyd CT, Underwood MJ, Gomes WJ, Angelini GD: On-pump versus off-pump coronary revascularization: evaluation of renal function. Ann Thorac Surg 1999;68:493-498.

$\checkmark 5$ Kavarana MN, Asher AS, Barbone A, Williams MR, Faber JM, Weinberg AD, Isidro AB, Oz MC, Esrig BC: A comparison of consecutive off-pump versus conventional coronary artery bypass. Heart Surg Forum 2001;4:160-165.

6 Levy JH, Tanaka KA: Inflammatory response to cardiopulmonary bypass. Ann Thorac Surg 2003;75:S715-S720.

7 Sabik JF, Gillinov AM, Blackstone EH, Vacha C, Houghtaling PL, Navia J, Smedira NG, McCarthy PM, Cosgrove DM, Lytle BW: Does off-pump coronary surgery reduce morbidity and mortality? J Thorac Cardiovasc Surg 2002;124: 698-707.

8 McBride WT, Armstrong MA, Crockard AD, McMurray TJ, Rea JM: Cytokine balance and immunosuppressive changes at cardiac surgery: contrasting response between patients and isolated CPB circuits. Br J Anaesth 1995;75: 724-733.

9 Wei M, Kuukasjarvi P, Laurikka J, Kaukinen S, Iisalo P, Laine S, Laippala P, Metsanoja R, Tarkka M: Cytokine responses and myocardial injury in coronary artery bypass grafting. Scand J Clin Lab Invest 2001;61:161-166.

10 Fujiwara T, Seo N, Murayama T, Hirata S, Kawahito K, Kawakami M: Transient rise in serum cytokines during coronary artery bypass graft surgery. Eur Cytokine Netw 1997;8:61-66.

-11 Eagle KA, Guyton RA, Davidoff R, Ewy GA, Fonger J, Gardner TJ, Gott JP, Herrmann HC, Marlow RA, Nugent W, et al: ACC/AHA guidelines for coronary artery bypass graft surgery: executive summary and recommendations: a report of the American College of Cardiology/American Heart Association Task Force on Practice Guidelines (Committee to revise the 1991 guidelines for coronary artery bypass graft surgery). Circulation 1999;100:1464-1480.

12 Cockcroft DW, Gault MH: Prediction of creatinine clearance from serum creatinine. Nephron 1976;16:31-41.

13 Potapov EV, Loebe M, Anker S, Stein J, Bondy S, Nasseri BA, Sodian R, Hausmann H, Hetzer R: Impact of body mass index on outcome in patients after coronary artery bypass grafting with and without valve surgery. Eur Heart J 2003; 24:1933-1941.

14 Gerritsen WB, van Boven WJ, Driessen AH, Haas FJ, Aarts LP: Off-pump versus on-pump coronary artery bypass grafting: oxidative stress and renal function. Eur J Cardiothorac Surg 2001;20:923-929.

15 Loef BG, Epema AH, Navis G, Ebels T, van Oeveren W, Henning RH: Off-pump coronary revascularization attenuates transient renal damage compared with on-pump coronary revascularization. Chest 2002;121:1190-1194.

16 Tang AT, Knott J, Nanson J, Hsu J, Haw MP, Ohri SK: A prospective randomized study to evaluate the renoprotective action of beating heart coronary surgery in low risk patients. Eur J Cardiothorac Surg 2002;22:118-123.

17 Karthik S, Musleh G, Grayson AD, Keenan DJ, Hasan R, Pullan DM, Dihmis WC, Fabri BM: Effect of avoiding cardiopulmonary bypass in non-elective coronary artery bypass surgery: a propensity score analysis. Eur J Cardiothorac Surg 2003;24:66-71. 


\section{CardioRenal Medicine}

\begin{tabular}{l|l}
\hline \multicolumn{2}{l}{ Cardiorenal Med 2012;2:190-199 } \\
\hline $\begin{array}{l}\text { DOI: 10.1159/000339171 } \\
\text { Published online: June 27, 2012 }\end{array}$ & $\begin{array}{l}\text { ( ) 2012 S. Karger AG, Basel } \\
\text { www.karger.com/crm }\end{array}$ \\
\hline
\end{tabular}

Nezami et al.: On- versus Off-Pump Coronary Artery Bypass Grafting: No Difference in

Early Postoperative Kidney Function Based on TNF- $\alpha$ or C-Reactive Protein

Magee MJ, Dewey TM, Acuff T, Edgerton JR, Hebeler JF, Prince SL, Mack MJ: Influence of diabetes on mortality and morbidity: off-pump coronary artery bypass grafting versus coronary artery bypass grafting with cardiopulmonary bypass. Ann Thorac Surg 2001;72:776-780; discussion 780-771.

19 Reston JT, Tregear SJ, Turkelson CM: Meta-analysis of short-term and mid-term outcomes following off-pump coronary artery bypass grafting. Ann Thorac Surg 2003;76:1510-1515.

20 Asimakopoulos G: Systemic inflammation and cardiac surgery: an update. Perfusion 2001;16:353-360.

21 Shlipak MG, Katz R, Cushman M, Sarnak MJ, Stehman-Breen C, Psaty BM, Siscovick D, Tracy RP, Newman A, Fried L: Cystatin-C and inflammatory markers in the ambulatory elderly. Am J Med 2005;118:1416.

-22 Keller CR, Odden MC, Fried LF, Newman AB, Angleman S, Green CA, Cummings SR, Harris TB, Shlipak MG: Kidney function and markers of inflammation in elderly persons without chronic kidney disease: the health, aging, and body composition study. Kidney Int 2007;71:239-244.

23 Kerr R, Stirling D, Ludlam CA: Interleukin 6 and haemostasis. Br J Haematol 2001;115:3-12.

24 Cermak J, Key NS, Bach RR, Balla J, Jacob HS, Vercellotti GM: C-reactive protein induces human peripheral blood monocytes to synthesize tissue factor. Blood 1993;82:513-520.

25 Morishige N, Tashiro T, Yamada T, Kimura M: Retrograde continuous warm blood cardioplegia reduces oxidative stress during coronary artery bypass grafting. Ann Thorac Cardiovasc Surg 2002;8:31-37.

-26 Biagioli B, Borrelli E, Maccherini M, Bellomo G, Lisi G, Giomarelli P, Sani G, Toscano M: Reduction of oxidative stress does not affect recovery of myocardial function: warm continuous versus cold intermittent blood cardioplegia. Heart 1997;77:465-473.

-27 Mezzetti A, Calafiore AM, Lapenna D, Deslauriers R, Tian G, Salerno TA, Verna AM, Bosco G, Pierdomenico SD, Caccurullo F: Intermittent antegrade warm cardioplegia reduces oxidative stress and improves metabolism of the ischemic-reperfused human myocardium. J Thorac Cardiovasc Surg 1995;109:787-795.

28 Wan S, Yim AP, Arifi AA, Lee TW, Huynh CH, DeSmet JM, LeClerc JL, Vincent JL: Can cardioplegia management influence cytokine responses during clinical cardiopulmonary bypass? Ann Thorac Cardiovasc Surg 1999;5:81-85.

29 Ohata T, Sawa Y, Kadoba K, Taniguchi K, Ichikawa H, Masai T, Shimazaki Y, Matsuda H: Normothermia has beneficial effects in cardiopulmonary bypass attenuating inflammatory reactions. ASAIO J 1995;41:M288-M291. 